\title{
The effect of poverty on the verbal scores of gifted students
}

\section{Fatih Kaya, Laura M. Stough \& Joyce Juntune}

To cite this article: Fatih Kaya, Laura M. Stough \& Joyce Juntune (2016): The effect of poverty on the verbal scores of gifted students, Educational Studies, DOI:

10.1080/03055698.2016.1148585

To link to this article: http://dx.doi.org/10.1080/03055698.2016.1148585

曲 Published online: 24 Feb 2016.

Submit your article to this journal

Q View related articles $\longleftarrow$

View Crossmark data \lceil 


\title{
The effect of poverty on the verbal scores of gifted students
}

\author{
Fatih Kaya ${ }^{a}$, Laura M. Stough ${ }^{b}$ and Joyce Juntune ${ }^{b}$ \\ aFaculty of Education, Department of Educational Sciences, Gaziosmanpasa University, Tokat, Turkey; ${ }^{b}$ College \\ of Education and Human Development, Department of Educational Psychology, Texas A\&M University, College \\ Station, TX, USA
}

\begin{abstract}
A nonexperimental design was used to determine whether the verbal scores of low-income gifted fifth graders $(n=38)$ differed from those of their higher income peers $(n=83)$. The Otis-Lennon School Ability Test, Eighth Edition and the Stanford Achievement Test-Tenth Edition were used to collect student data. Results of a MANOVA showed a statistically significant difference between the verbal scores of the two groups, with low-income students scoring significantly lower. A large effect size for the multivariate main effect of income level on verbal intelligence and verbal achievement scores was found $\left(\eta^{2}=.19\right)$. The existence of verbal-nonverbal score discrepancy in low-income students questions the practice of using only nonverbal or nonverbal parts of an IQ test to identify and place students in gifted programmes. These results also underscore the need to nurture underdeveloped verbal abilities when they occur in low-income students.
\end{abstract}

\section{ARTICLE HISTORY}

Received 16 May 2015

Accepted 24 December 2015

\section{KEYWORDS}

Poverty; gifted students; achievement; verbal ability

Poverty is a factor shown to predict both academic and social accomplishment (Berliner and Biddle 1995; Carman and Taylor 2010; Gottfried et al. 2003; Lee and Burkam 2002; Tyler-Wood and Carri 1993; White 1982). Specifically, poverty can negatively influence the development of verbal skills as they are highly correlated with school achievement (Hart and Risley 1995). Researchers have observed that students raised in poverty exhibit lower verbal skills even while simultaneously evidencing average- or above-average nonverbal skills (Juntune, Kaya, and Ramos 2011; Tyler-Wood and Carri 1993). Reardon (2011) examined the data from 19 nationally representative studies that focused on the relationship between socio-economic status (SES) and academic achievement as measured by reading and math scores. Evidence strongly suggested that the achievement gap between children from upper and lower income families has grown over the past several decades. In fact, some researchers (e.g. Burney and Beilke 2008) have argued that poverty may be the most important factor in explaining the current achievement gap among students in the USA.

Studies on school success usually employ discrete variables such as ethnicity, gender, culture, language and school location. While there is some debate on how these variables should be measures, "poverty" is typically measured using family income while "SES" typically includes measures such as parental educational level and type of occupation to the mix. As poverty is actually a complex set of conditions rather than a discrete independent variable 
(Burney and Beilke 2008), other demographic variables, such as ethnicity and school location, may camouflage the influence of poverty (e.g. Banks 2010; Lichter, Zhenchao, and Martha 2006; Rothstein 2004; Skiba et al. 2005).

In the USA, "poverty level" or "low-income" students are typically identified based on their eligibility for the U.S. Federal Free or Reduced Lunch Programme. The Free or Reduced Lunch programme provides low-cost or free school lunch meals through subsidies to schools and currently serves over 30 million US school children each day. The U.S. Bureau of the Census (2012) similarly uses family income level, along with family size, to determine poverty status. In the 2010 Census, 38.2\% of African-Americans, 32.3\% of Hispanics, $17 \%$ of whites, $13 \%$ of Asian Americans and $22 \%$ of all children under age 18 were determined to be living in poverty in the USA (U.S. Bureau of the Census 2010).

\section{The poverty-achievement relationship}

Academic achievement is of primary concern to educators, policy-makers and parents. It has long been recognised that children from low-SES families demonstrate lower academic achievement than do their peers from middle-class families (Caldas and Bankston 1997; Vista and Grantham 2010). White (1982) conducted a meta-analysis to examine the relationship between SES and academic achievement. Based on a review of almost 200 studies, White found SES was usually defined using the income level, education or occupation of the head of the household. In these studies, the correlation between SES and academic achievement varied between .22 and .73, depending on factors such as type of academic achievement measure, type of SES measure, the year in which the data were collected and the grade level at which the measurement was taken. However, White concluded that the overall best predictor of academic achievement, among other indicators of SES, was family income, followed by parental occupation, and then level of parental education. These findings were replicated in a more recent meta-analytic review (Sirin 2005).

Other research has demonstrated the enduring influence of SES on academic achievement. For example, Berliner and Biddle (1995) found that students living in poverty exhibited more educational difficulties than did students from wealthy, middle-class or working-class families. Jencks and Phillips (1998) determined that as much as one-third of the achievement gap could be explained by socio-economic variables. Lee and Burkam (2002) replicated the findings of previous research showing that children of higher income and from more highly educated families tended to perform better in school. In addition, high-income level has been associated with rich learning environments, which are vital for positive cognitive development (Duncan et al. 1998).

In contrast, lower family income has been shown to have a negative effect on the identification and subsequent education of high-ability children (Milne et al. 1986). Smith, Brooks-Gunn, and Klebanov (1997) investigated the effect of family income on quality home environment, and found that differences between the home environments of high- and low-income children explained one-third of the effect of income on academic achievement in elementary students. Lower income also leads to decreased educational opportunities. Lee and Burkam (2002) point out an opportunity gap exists between low- and high-income children even before they start to school. For example, children of parents with higher educational levels have more books in the home, are read to more frequently and thus have more interactive reading and conversation opportunities than do children of less educated 
families (Bianchi and Robinson 1997; Chatterji 2006; West, Denton, and Germino-Hausken 2000). Once children begin school, middle-class families typically have better access to good teachers and curricula (Margolin 1994; Useem 1992) as well as to cultural learning opportunities that contribute to student advantage in the classroom (DiMaggio 1982). Alternatively, low-income schools in the USA historically have less experienced or qualified teachers (Kozol 1991) and less likely to offer advanced placement (AP) courses and challenging curricula (Martin, Karabel, and Vasquez 2005); all factors that can negatively affect academic outcomes.

\section{Gifted students from low SES backgrounds}

Typically, it is more difficult to identify low-SES gifted students (Slocumb 2001). Underrepresentation of low-SES students in gifted and talented education programmes appears to be related to lower verbal scores used as part of the identification process. TylerWood and Carri (1993) compared the scores of low, average and above-average SES students in fourth to eighth grades on the Cognitive Abilities Test (CogAT), the Stanford-Binet and the Slosson intelligence tests. Verbal scores were significantly lower in low-SES groups than those of other groups on all three tests. In a similar study Saccuzzo, Johnson, and Russell (1992) evaluated the verbal and performance scores of 4546 diverse gifted students in grades one through nine. Results showed that students' verbal and performance score patterns were dependent on ethnicity or on the interaction of ethnicity with other achievement areas.

Juntune, Kaya, and Ramos (2011) gathered two years of data on 572 low-SES, mixed-ability, first- through third-grade students using the Reynolds Intellectual Assessment Scale (RIAS; Reynolds and Kamphaus 2003). The authors found statistically significant large gaps between students' verbal and nonverbal intelligence scores, with the nonverbal scores being higher in low-SES students. The difference between the nonverbal and the verbal intelligence scores was 23.3 points, 22.1 points and 20.2 points for first, second and third graders, respectively. Cohen's $d$ effect size ranged from 1.27 to 1.44 . The researchers suggested that lower verbal scores signalled that low-SES students may face challenges in advanced academic courses, which often have strong verbal components.

Many school districts in the USA have increasingly used nonverbal ability test or nonverbal subtests of any intelligence test to identify and place underrepresented low-SES and minority students into gifted education programmes (Lakin and Lohman 2011; Lewis et al. 2007; Saccuzzo, Johnson, and Russell 1992). Although these practices may increase the number of low-SES and minority students in gifted programmes, these practices also have drawbacks. Students placed into gifted programmes by virtue of their high nonverbal scores alone face challenges in programmes with require high verbal skills. In addition, verbal intelligence scores have greater predictive validities of achievement than do nonverbal scores (Benbow and Stanley 1996; Lakin and Lohman 2011). Gifted identification procedures thus should be carefully considered so that they match the demands of gifted programmes and curriculum (Benbow and Stanley 1996; Lohman 2005).

For example, in the USA, school districts are mandated to modify, differentiate and enrich their regular curriculum and instruction to meet gifted students' needs. A typical practice at the high school level is to offer AP courses, and pre-AP courses as a form of gifted services. The AP programme was created by the US College Board for high-achieving students. The programme offers college-level courses with trained high school teachers in various subject areas including English, Biology, Calculus, Art, History and Environmental Sciences. Most AP 
courses require a high level of verbal ability and require strong reading and writing skills. Students admitted to AP courses primarily on the basis of their nonverbal achievement scores will be understandably challenged, given the content of these courses.

Early identification of high-achieving as well as gifted and talented students is crucial for developing appropriate programmes that meet gifted students' needs (Colangelo and Davis 2003). Several researchers (e.g. Moore et al. 2006; Trusty, Niles, and Carney 2005) claim that students who complete challenging courses, such as math and science, in lower grades are more likely to be successful in upper grades. Conversely, they argue, if students are exposed to less challenging courses, it is difficult for them to succeed in demanding courses in upper grades. Adelman (2006) has provided evidence that the satisfactory completion of advanced courses is the most important predictor of post-secondary success.

\section{Purpose of the study}

In this study, we investigated the relationship between gifted fifth-grade students' verbal scores and income status. The following research question guided the study: What is the relationship between verbal scores and the income status of fifth-grade gifted students? Our hypothesis was that low-income gifted fifth-grade students would have lower verbal scores on the Stanford Achievement Test (SAT-10, 2002) than did higher income students.

\section{Method}

A nonexperimental design was used to examine whether the verbal scores of gifted fifth graders categorised as low-income differed from those with higher income status. Income status was based on students' free or reduced-price lunch programme status. Participation in the U.S. lunch programme has been used frequently by other researchers (i.e. Goddard, Salloum, and Berebitsky 2009; Jones and Gansle 2010; Skiba et al. 2005; Warne, Anderson, and Johnson 2013) as a proxy for living in poverty.

\section{Participants}

The sample consisted of 128 gifted fifth graders from 5 schools. Each student had been identified as gifted by the school district based on several assessment tools including standardised intelligence and achievement tests, teacher and parent nomination forms and student portfolios. Two groups of gifted fifth-grade students made up the sample: 38 (31.4\%) students who were on the free or reduced-price lunch programme and 83 (68.6\%) students who were not on the free or reduced-price lunch programme. Fifth graders were the focus of the study as fifth grade typically denotes the last year of elementary school in the USA. In addition, achievement tests are usually administered during fifth grade to identify students ready for advanced level courses in grade six.

While ethnicity and bilingualism were not directly measured in the current study, the sample came from a school district that was overwhelmingly of Hispanic descent. According to the Texas Education Agency (2013), there were 82.6\% Hispanic, 10.6 white and $4.1 \%$ African-American students enrolled in the school district during 2012-2013 academic year. In addition, $69.7 \%$ were labelled as economically disadvantaged and $24.6 \%$ were English Language Learners (ELL). Students attending bilingual or English as a Second Language 
(ESL) programmes were not included in the current sample. Therefore, students with a native language other than English were excluded from the analysis.

\section{Instruments}

The Otis-Lennon School Ability Test, Eighth Edition (OLSAT 8; Otis and Lennon 2003) and the Stanford Achievement Test-Tenth Edition (SAT, 2002) were used to assess students' verbal performance. The OLSAT 8 (Otis and Lennon 2003) is the latest version in a series of ability tests designed to measure verbal, quantitative and figural reasoning skills of students from kindergarten through grade 12. It is a group-administered assessment of the abilities most closely related to scholastic achievement. It assesses students' ability to cope with school learning tasks and evaluates their achievement in relation to the talents they bring to the school learning environment. Some of the tasks that assess those abilities involve detecting similarities and differences, solving analogies and matrices, classifying and determining sequence. The theoretical framework for the OLSAT 8 (Otis and Lennon 2003) is based on a hierarchical model of human cognitive abilities (e.g. Carroll 1993). According to the authors, the standardisation sample represents the national school population in terms of ethnicity, SES, geographic region and urbanicity (Otis and Lennon 2003). The OLSAT 8 (Otis and Lennon 2003) provides verbal and nonverbal subtest scores in addition to a total school learning ability score. It has one form with seven levels, each of which is grade specific. Level E was developed for the grades four and five; therefore, it was used for the fifth graders in the current study. A total of 36 items assess verbal ability and 36 items assess nonverbal ability in Level E. The OLSAT 8 (Otis and Lennon 2003) was standardised concurrently with the SAT (2002). Comparing the OLSAT scores and achievement or scholastic aptitude scores indicated the validity. The reliability of the OLSAT was determined on the basis of three procedures. The Kuder-Richardson produced internal consistency coefficients between .90 and .94. Testretest and alternate-form reliability coefficients were also calculated and found between .82 and .92 . The validity of the test was assessed by determining the correlation between the OLSAT scores and teacher grades as well as the comparison of the OLSAT scores with achievement and aptitude scores. The correlations fall within a range of .40-.60.

The SAT (2002) was designed to measure achievement in reading, mathematics, language, environment/science, social science, spelling, study skills, thinking skills and listening. The test comprises 13 battery levels that assess students from kindergarten through grade 12. There is a full-length Complete Battery and an Abbreviated Battery, which is the shortened version of selected subtests. Each of these configurations (13 battery levels and 2 battery options for each level) can be administered with optional subtests and provides domain and battery total scores. The test includes three types of questions: multiple choice, short answer and extended response. As a norm-referenced measure, the SAT-10 provides not only a valid and reliable achievement scores, but also the relative standing of tested students' academic performance compared to the performance of students from a nationally representative sample (Taylor 2006; Venn 2007). The norm sample of the current test was updated in 2007 (SAT, 2002). In this study, vocabulary, reading comprehension, language and spelling subtests (verbal subtests) of the Abbreviated Battery (Form D-Intermediate 2) were used. The SAT-10 reported a high degree of internal consistency reliability. The coefficients ranged between the mid .80s.90s (Carney and Morse 2005). Alternate-form reliability for the SAT-10 was similar 
Table 1. Correlations among vocabulary, reading comprehension, spelling, language, verbal intelligence, nonverbal intelligence and composite intelligence.

\begin{tabular}{lcccccccc}
\hline & & & & & Verbal & Nonverbal \\
SAT-10 & Vocabulary & Vocabulary & Reading & Spelling & Language & IQ & IQ & Composite IQ \\
\hline & Reading & $.455^{*}$ & 1 & & & & & \\
& Spelling & $.407^{*}$ & $.578^{*}$ & 1 & & & & \\
Language & $.453^{*}$ & $.632^{*}$ & $.591^{*}$ & 1 & & & \\
OLSAT 8 & $\begin{array}{l}\text { Verbal IQ } \\
\text { Nonverbal }\end{array}$ & $.357^{*}$ & $.459^{*}$ & $.437^{*}$ & $.438^{*}$ & 1 & & \\
& IQ & $.260^{*}$ & $.345^{*}$ & $.275^{*}$ & $.364^{*}$ & $.802^{*}$ & 1 & \\
& Composite & $.272^{*}$ & $.321^{*}$ & $.263^{*}$ & $.301^{*}$ & $.649^{*}$ & $.616^{*}$ & 1 \\
& IQ & & & & & & & \\
\hline
\end{tabular}

*Correlation significant at the 0.01 level (two-tailed).

to the relationship between the subtests. As for the validity of the SAT-10, convergent validity is demonstrated by correlations in the $.70-.80$ range made between subtests of the SAT- 9 and subtests of the SAT-10. Construct validity was demonstrated with reasonable correlations between the SAT-10 and the OLSAT-8 (Carney and Morse 2005).

\section{Procedures}

Students'scores on the OLSAT 8 and the SAT-10 in 2012, along with demographic information and free- or reduced-price lunch status for each student, were obtained from the school district. The students were divided into two groups as (a) students receiving free or reducedprice lunch and (b) students not receiving free or reduced-price lunch. Students' achievement scores on the SAT-10 and verbal intelligence scores on the OLSAT 8 were compared across their free or reduced-price lunch status.

\section{Data analysis}

The independent variable was income status and used free or reduced-price lunch programme status as a proxy measure. The dependent variables were verbal intelligence scores on the OLSAT 8 and the vocabulary, reading comprehension, language and speaking achievement scores on the SAT-10.

A Pearson product-moment correlation analysis was conducted to examine the relationship between verbal and nonverbal intelligence scores, and achievement scores in the domains of vocabulary, reading comprehension, language and spelling. Further, a multivariate analysis of variance (MANOVA) was performed to investigate the effects of income status on all dependent variables simultaneously by considering the interrelationships among the dependent variables (Fausset, Rogers, and Fisk 2009; Grimm and Yarnold 2006). There are several assumptions behind a MANOVA, including multivariate normality, linearity of relationships, low influence of univariate and multivariate outliers, homogeneity of variance-covariance matrices and an absence of multicollinearity. Each assumption was tested, and no serious violations were noted. 


\section{Results}

Correlation analysis resulted in moderate correlations among all variables. The correlation between achievement scores and verbal IQ scores was also higher than the correlation with nonverbal IQ scores (see Table 1).

Table 2 provides the mean and the standard deviation scores for each of the dependent variables split by the independent variable. As illustrated, for all dependent variables, the mean scores of the students receiving free or reduced-price lunch were consistently lower than those of students not receiving free or reduced-price lunch. Calculated Cohen's $d s$ for each dependent variable ranged from .68 to .83 .

The results of the one-way MANOVA are displayed in Table 3. As illustrated, a statistically significant multivariate main effect was found for free or reduced-price lunch programme status, $F(5,115.000)=5.43, p<.05 ;$ Wilks' $^{\prime} \lambda=.809 ; \eta^{2}=.19$. The observed power to detect the effect was .988 .

Given the significance of the overall test, it was deemed important to look at each dependent variable using separate ANOVA tests. These separate ANOVA tests do not take possible intercorrelations among the dependent variables into account. A univariate main effect for each dependent variable was examined and is shown in Table 3.

Table 2. Descriptive statistics for vocabulary, reading comprehension, language, spelling and verbal intelligence by free or reduced-price lunch status.

\begin{tabular}{lccccc}
\hline & Free/reduced-price lunch & $M$ & SD & $N$ & Cohen's d \\
\hline Vocabulary & Yes & 669.18 & 44.022 & 38 & \\
& No & 697.39 & 33.708 & 83 & .72 \\
Reading comprehension & Total & 688.53 & 39.328 & 121 & \\
& Yes & 664.21 & 34.880 & 38 & .71 \\
Language & No & 690.35 & 38.239 & 83 & \\
& Total & 682.14 & 39.022 & 121 & .83 \\
Spelling & Yes & 631.34 & 34.584 & 38 & \\
& No & 659.54 & 33.722 & 83 & \\
Verbal intelligence & Total & 650.69 & 36.313 & 121 & .80 \\
& Yes & 638.79 & 46.490 & 38 & \\
& No & 677.51 & 50.180 & 83 & \\
\end{tabular}

Table 3. The effect of poverty on verbal intelligence and achievement scores.

\begin{tabular}{|c|c|c|c|c|c|c|c|c|}
\hline Source & Dependent variable & $\begin{array}{c}\text { Wilks' } \\
\text { lambda }\end{array}$ & $d f$ & $F$ & Sig. & $\eta^{2}$ & $\begin{array}{c}\text { Noncent. } \\
\text { param- } \\
\text { eter }\end{array}$ & $\begin{array}{c}\text { Observed } \\
\text { power }^{\mathrm{a}}\end{array}$ \\
\hline $\begin{array}{l}\text { Free or } \\
\quad \text { reduced- }\end{array}$ & $\begin{array}{c}\text { Combined verbal } \\
\text { scores }^{\mathrm{a}}\end{array}$ & .809 & 5 & 5.431 & $.000^{c}$ & .191 & 27.153 & .988 \\
\hline \multirow[t]{5}{*}{ lunch status } & Vocabulary ${ }^{b}$ & - & 1 & 14.963 & $.000^{c}$ & .112 & 14.963 & .970 \\
\hline & Reading $^{b}$ & - & 1 & 12.851 & $.000^{c}$ & .097 & 12.851 & .945 \\
\hline & Language $^{b}$ & - & 1 & 17.939 & $.000^{c}$ & .131 & 17.939 & .987 \\
\hline & Spelling ${ }^{b}$ & - & 1 & 16.232 & $.000^{c}$ & .120 & 16.232 & .979 \\
\hline & Verbal intelligence $^{b}$ & - & 1 & 11.426 & $.001^{\mathrm{c}}$ & .088 & 11.426 & .918 \\
\hline
\end{tabular}

aMANOVA design: intercept + free or reduced-price lunch status.

bUnivariate ANOVAs.

'Computed using alpha $=.05$. 
Statistically significant univariate main effects of the free or reduced-cost lunch status were obtained for vocabulary, $F(1,119)=14.96, p<.05, \eta^{2}=.11$, power $=.970$; reading comprehension, $F(1,119)=12.85, p<.05, \eta^{2}=.10$, power $=.945$; language, $F(1,119)=17.94$, $p<.05, \eta^{2}=.13$, power $=.987$; spelling, $F(1,119)=16.23, p<.05, \eta^{2}=.12$, power $=.979$; and verbal intelligence, $F(1,119)=11.43, p<.05, \eta^{2}=.09$, power $=.918$.

To summarise, according to the results of the MANOVA, there was a statistically significant difference between the students receiving free or reduced-price lunch and the students not receiving free or reduced-price lunch on the combined dependent variables. When the results for the dependent variables were examined separately, there was statistically significant difference for each dependent variable. An inspection of the mean scores revealed that students who were not receiving free or reduced-price lunch had higher verbal scores than did students receiving free or reduced-price lunch. An effect size of $\eta^{2}=.19$ was found for the multivariate main effect of the free or reduced-price lunch programme status. As for the univariate main effects of the free or reduced-price lunch programme status, effect sizes ranging from $\eta^{2}=.09$ for verbal intelligence to $\eta^{2}=.13$ for language were obtained.

\section{Discussion}

Statistically significant differences in verbal intelligence and on all measures of academic achievement were found for low-income students, as defined by free- or reduced-price lunch status. Results of the MANOVA provided a large effect size $\left(\eta^{2}=.19\right)$, meaning that free- or reduced-price lunch status accounted for $19 \%$ of the variability in the scores on all dependent variables. In addition, univariate findings indicated statistically significant differences on each of the dependent variables based on free- or reduced-price lunch status. The calculated effect sizes are: $\eta^{2}=.09$ for verbal intelligence, $\eta^{2}=.10$ for reading comprehension, $\eta^{2}=.11$ for vocabulary, $\eta^{2}=.12$ for spelling and $\eta^{2}=.13$ for language.

In sum, higher income students (i.e. those not qualifying for the free or reduced-price lunch programme at school) had higher means on all of the dependent variables than did the students classified as low-income (i.e. qualifying for the free or reduced-price lunch programme at school). These results suggest that significant differences in students' verbal intelligence scores as well as in vocabulary, reading comprehension, language and spelling achievement scores were associated with students' household income level.

Scholars have explored the disparities in academic achievement and educational outcome based on poverty status for several decades (e.g. Berliner and Biddle 1995; Carman and Taylor 2010; Coleman 1966; Payne 2005; White 1982). The results of the present study replicated the results of many previous studies (e.g. Abbott and Joireman 2001; Carman and Taylor 2010; Entwisle, Alexander, and Olson 1997; Lee and Burkam 2002; Lohman, Korb, and Lakin 2008; Smith, Brooks-Gunn, and Klebanov 1997).

\section{Conclusion and implications}

Results of the study suggest that free- or reduced-price lunch status is a powerful predictor of verbal intelligence scores as well as of achievement scores. The existence of a verbal-nonverbal score discrepancy in low-income students questions the practice of using nonverbal IQ scores as a sole measure for identification and placement in gifted programmes. While nonverbal tests may allow more low-income students to be placed in gifted and talented 
programmes or in advanced academic courses, the use of nonverbal tests may have unintended negative consequences. Much of the schoolwork in gifted programmes (e.g. AP courses) requires strong verbal skills. Moreover, as pointed out by Lohman (2005), abilities measured with tests should be matched by the demands that gifted programmes and advanced programmes make on students. That is, the verbal demands of these programmes must be able to be met by the verbal abilities of the students that are accepted into them.

Research evidence and educational policy lend importance to offering advanced courses for high-achieving and high-ability students. The primary purpose for such courses should not only be to identify each student's potential for the advanced programmes, but also to provide appropriate learning experiences within those programmes. We concur with Ross (2006) that while much attention has been spent on the identification of gifted students, an equal amount of effort should be spent on examining the content of these advanced programmes. It is critical to deliver the most effective curriculum and instructional strategies that match gifted student abilities.

Underdeveloped verbal abilities of low-income students should be carefully nurtured through educational intervention programmes (Warne 2009). Building the verbal intelligence of low-income students identified as gifted will support their success in academic coursework that requires high verbal ability. Specifically, instructional activities that build complex language and verbal memory are needed for gifted students with low verbal abilities. Such programmes should be implemented as early as possible so that students can develop their verbal abilities before important placement decisions in fifth or sixth grade are made for advanced programmes that typically take place at the secondary level.

As stated by several scholars (e.g. Cattell 1971; Cattell and Horn 1978; Reynolds and Kamphaus 2003), nonverbal scores or fluid intelligence indicate the potential to learn, whereas verbal scores or crystallised intelligence indicate readiness to learn. The results of the present study showed that while many students with high nonverbal scores may have the potential to learn, their lower verbal scores indicate that they have not been adequately prepared for advance coursework. Students, even when gifted, can be predicted to struggle in advanced academic coursework when their verbal skills do not match the verbal demands of these programmes (Lohman 2005).

Educators responsible for gifted programmes should be aware of the costs versus benefits of three different identification options. The first is to identify students on the basis of higher verbal scores. The drawback is this procedure typically results in underrepresentation of students from low-income backgrounds. The second option is to identify students using nonverbal scores; however, high nonverbal abilities along with underdeveloped verbal abilities can create challenges for these students, given the verbal context of the gifted programme. The third option is to nurture the verbal abilities of children raised in poverty, including quality of conversation at school, increasing the amount of time students read and the use of teaching strategies that emphasise verbal development. The role of poverty in suppressing verbal abilities should be considered as part of the gifted identification process and programme development for gifted students. Finally, when low-income students with lower verbal scores are placed into gifted and talented or advanced academic programmes, additional measures that closely track the academic performance of these students are recommended. 


\section{Limitations and further research}

Students' ethnicity and language status were not added as covariates in this study. It is recommended that future research include these variables in order to explore their composite and unique effects on verbal and nonverbal scores in low-income students, particularly as these variables often correlate with poverty (Lohman and Gambrell 2012; Warne, Anderson, and Johnson 2013). Other factors for investigation include the quality of the school and home environments, parents' educational backgrounds and the first language of family may also influence verbal scores and their relation with poverty. Longitudinal intervention programmes that build verbal intelligence should also be conducted to follow students'academic performance from their early years in elementary school to their transition to upper grades. Finally, further research is needed to understand how low-income status differentially affects both the verbal and nonverbal abilities of students.

\section{Disclosure statement}

No potential conflict of interest was reported by the authors.

\section{Notes on contributors}

Fatih Kaya, PhD, is an assistant professor in the Department of Educational Sciences at Gaziosmanpasa University in Tokat, Turkey. He is also the department head for special education. He received his bachelor's degree from Bogazici University in Istanbul, Turkey and his doctoral degree in educational psychology, specialisation in Gifted and Talented Education, from Texas A\&M University. He currently teaches graduate and undergraduate courses at Gaziosmanpasa University. His research interest includes gifted and talented education, gifted identification, intelligence, achievement and testing.

Laura M. Stough, PhD, is an associate professor in the Department of Educational Psychology at Texas A\&M University in College Station, TX. She received her bachelor's degree from University of California at Los Angeles and master's and doctoral degrees from University of Texas at Austin. She teaches graduate courses in disability studies and qualitative research. She is a departmental ombudsperson. Her research interest includes classroom management, disaster and disability, intellectual disabilities and international education.

Joyce Juntune, $\mathrm{PhD}$, is an instructional associate professor in the Department of Educational Psychology at Texas A\&M University in College Station, TX. She received her bachelor's and master's degrees while living in Minnesota and her PhD from Texas A\&M University. She currently teaches graduate and undergraduate courses in educational psychology, child development, intelligence and creativity. Juntune also serves as the programme coordinator for the undergraduate minor in Creative Studies at Texas A\&M University.

\section{References}

Abbott, M. L., and Joireman, J. 2001. The Relationships among Achievement, Low Income, and Ethnicity across Six Groups of Washington State Students (Technical Report No. 1). Lynnwood, WA: Washington School Research Center.

Adelman, C. 2006. The Toolbox Revisited: Paths to Degree Completion from High School through College. Washington, DC: U.S. Department of Education.

Banks, J. A.. 2010. Multicultural Education: Characteristics and Goals. In Multicultural Education: Issues and Perspectives. (7th ed.), edited by J. A. Banks and C. A. M. Banks, 3-30. Hoboken, NJ: John Wiley.

Benbow, C. P., and J. C. Stanley. 1996. "Inequity in Equity: How "Equity" Can Lead to Inequity for HighPotential Students." Psychology, Public Policy, and Law 2 (2): 249-292. doi:10.1037//1076-8971.2.2.249. 
Berliner, D. C., and B. J. Biddle. 1995. The Manufactured Crisis: Myths, Fraud, and the Attack on America's Public Schools. Reading, MA: Addison-Wesley. doi:10.1177/019263659608057619.

Bianchi, S., and J. Robinson. 1997. "What Did You Do Today? Children's Use of Time, Family Composition, and the Acquisition of Social Capital." Journal of Marriage \& Family 59: 332-344. doi: $10.2307 / 353474$.

Burney, V. H., and J. R. Beilke. 2008. "The Constraints of Poverty on High Achievement." Journal for the Education of the Gifted 31: 171-197.

Caldas, S. J., and C. L. Bankston. 1997. “Effect of School Population Socioeconomic Status on Individual Academic Achievement." The Journal of Educational Research 90: 269-277. doi:10.1080/00220671. 1997.10544583.

Carman, C. A., and D. K. Taylor. 2010. "Socioeconomic Status Effects on Using the Naglieri Nonverbal Ability Test (NNAT) to Identify the Gifted/Talented." Gifted Child Quarterly 54: 75-84. doi: $10.1177 / 0016986209355976$.

Carney, R. N., and Morse, D. T. 2005. "Reviews of the Stanford Achievement Test, Tenth Edition." In The Sixteenth Mental Measurements Yearbook, edited by R. A., Spies, and B. S. Plake, 969-975. Lincoln, NE: Buros Institute of Mental Measurements.

Carroll, J. B. 1993. Human Cognitive Abilities. New York: Cambridge University Press.

Cattell, R. B. 1971. Abilities: Their Structure, Growth, and Action. Boston, MA: Houghton-Mifflin.

Cattell, R. B., and J. L. Horn. 1978. "A Check On the Theory of Fluid and Crystallized Intelligence with Description of New Subtest Designs." Journal of Educational Measurement 15: 139-164. doi: 10.1111/j.1745-3984.1978.tb00065.x.

Chatterji, M. 2006. "Reading Achievement Gaps, Correlates, and Moderators of Early Reading Achievement: Evidence from the Early Childhood Longitudinal Study (ECLS) Kindergarten to First Grade Sample." Journal of Educational Psychology 98: 489-507. doi:10.1037/0022-0663.98.3.489.

Colangelo, N., and G. A. Davis. 2003. Handbook of Gifted Education. 3rd ed. Boston, MA: Allyn \& Bacon. Coleman, J. S. 1966. Equality of Educational Opportunity. Washington, DC: U.S. Office of Education.

DiMaggio, P. 1982. "Cultural Capital and School Success: The Impact of Status Culture Participation on the Grades of U.S. High School Students." American Sociological Review 47: 189-201. doi: $10.2307 / 2094962$.

Duncan, G. J., W. J. Yeung, J. Brooks-Gunn, and J. R. Smith. 1998. "How Much Does Childhood Poverty Affect the Life Chances of Children?" American Sociological Review 63: 406-423. doi: $10.2307 / 2657556$.

Entwisle, D., K. Alexander, and L. S. Olson. 1997. Children, Schools, \& Inequality. Boulder, CO: Westview Press.

Fausset, C. B., W.A. Rogers, \& A.D. Fisk. 2009. Univariate and Multivariate Analysis of Variance: A Primer (HFA-TR-0904). Atlanta, GA: Georgia Institute of Technology, School of Psychology, Human Factors and Aging Laboratory.

Goddard, R. D., S. J. Salloum, and D. Berebitsky. 2009. “Trust as a Mediator of the Relationships between Poverty, Racial Composition, and Academic Achievement: Evidence from Michigan's Public Elementary Schools." Educational Administration Quarterly 45 (2): 292-311.

Gottfried, A. W., A. E. Gottfried, K. Bathurst, and D. W. Guerin. 2003. "Socioeconomic Status in Children's Development and Family Environment: Infancy through Adolescence." In Socioeconomic Status, Parenting and Child Development, edited by M. H., Bornstein and R. H. Bradley, 189-207. Mahwah, $\mathrm{NJ}$ : Lawrence Erlbaum.

Grimm, L. G., and P. R. Yarnold. 2006. Reading and Understanding Multivariate Statistics. Washington, DC: American Psychological Association.

Hart, B., and T. R. Risley. 1995. Meaningful Differences in the Everyday Experience of Young American Children. Baltimore, MD: Paul H Brookes.

Jencks, C., and M. Phillips. 1998. The Black-White Test Score Gap. Washington, DC: Brookings Institution. Jones, B. A., and K. A. Gansle. 2010. "The Effects of a Mini-Conference, Socioeconomic Status, and Parent Education on Perceived and Actual Parent Participation in Individual Education Program Meetings." Research in the Schools 17: 23-38.

Juntune, J., F. Kaya, and S. Ramos. 2011. "Another Look at High Ability Students from Low SES Populations." Tempo 32 (4): 14-19. 
Kozol, J. 1991. Savage Inequalities. New York: Harper.

Lakin, J. M., and D. F. Lohman. 2011. "The Predictive Accuracy of Verbal, Quantitative, and Nonverbal Reasoning Tests: Consequences for Talent Identification and Program Diversity." Journal for the Education of the Gifted 34 (4): 595-623. doi:10.1177/016235321103400404.

Lee, V. E., and D. T. Burkam. 2002. Inequality at the Starting Gate: Social Background Differences in Achievement as Children Begin School. Washington, DC: Economic Policy Institute.

Lewis, J. D., S. S. DeCamp-Fritson, J. C. Ramage, M. A. McFarland, and T. Archwamety. 2007. "Selecting for Ethnically Diverse Children Who May Be Gifted Using Raven's Standard Progressive Matrices and Naglieri Nonverbal Abilities Test." Multicultural Education 15 (1): 38-42.

Lichter, D. T., Q. Zhenchao, and C. Martha. 2006. “Race and Poverty: Divergent Fortunes of America's Children?" Focus 24 (3): 8-16.

Lohman, D. F. 2005. “The Role of Nonverbal Ability Tests in Identifying Academically Gifted Students: An Aptitude Perspective." Gifted Child Quarterly 49: 111-138. doi:10.1177/001698620504900203.

Lohman, D. F., and J. L. Gambrell. 2012. "Using Nonverbal Tests to Help Identify Academically Talented Children." Journal of Psychoeducational Assessment 30: 25-44. doi: $10.1177 / 0734282911428194$.

Lohman, D. F., K. Korb, and J.Lakin. 2008. “Identifying Academically Gifted English-Language Learners Using Nonverbal Tests: A Comparison of the Raven, NNAT, and CogAT." Gifted Child Quarterly 52:275-296. doi: $10.1177 / 0016986208321808$.

Margolin, L. 1994. Goodness Personified. Albany, NY: State University of New York Press.

Martin, I., J. Karabel, and S. Vasquez. 2005. "High School Segregation and Access to the University of California." Educational Policy 19: 308-330. doi:10.1177/0895904804274058.

Milne, A. M., D. E. Myers, A. S. Rosenthal, and A. Ginsburg. 1986. "Single Parents, Working Mothers, and the Educational Achievement of School Children." Sociology of Education 59: 125-139. doi: $10.2307 / 2112335$.

Moore III, J. L., D. Y. Ford, D. Owens, T. Hall, M. Byrd, M. S. Henfield, and G. Whiting. 2006. “Retention of African-Americans in Gifted Education: Lessons Learned from Higher Education." Midwestern Educational Research Journal 19: 3-12.

Otis, A. S., and R. T. Lennon. 2003. Otis-Lennon School Ability Test (OLSAT) Technical Manual. 8th ed. San Antonio, TX: Harcourt Brace Educational Measurement.

Payne, R. 2005. A Framework for Understanding Poverty. Highlands, TX: Aha! Process Inc.

Reardon, S. F. 2011. "The Widening Academic Achievement Gap between the Rich and the Poor: New Evidence and Possible Explanations." In Whither Opportunity? Rising Inequality and the Uncertain Life Chances of Low-Income Children, edited by R., Murnane, and G. Duncan, 91-116. New York: Russell Sage Foundation Press.

Reynolds, C. R., and R. W. Kamphaus. 2003. Reynolds Intellectual Assessment Scales and the Reynolds Intellectual Screening Test Professional Manual. Lutz, FL: Psychological Assessment Resources.

Ross, P. O. 2006. "What Works? Successful Initiatives with Promising Learners from Poverty." Presentation at the william \& mary and national association for gifted children national leadership conference on low-income promising learners, Washington, DC, April.

Rothstein, R. 2004. Class and Schools: Using Social, Economic, and Educational Reform to Close the BlackWhite Achievement Gap. Washington, DC: Economic Policy Institute.

Saccuzzo, D. P., N. E. Johnson, and G. Russell. 1992. "Verbal versus Performance IQs for Gifted AfricanAmerican, Caucasian, Filipino, and Hispanic Children." Psychological Assessment 4: 239-244. doi: 10.1037//1040-3590.4.2.239.

Sirin, S. R. 2005. "Socioeconomic Status and Academic Achievement: A Meta-Analytic Review of Research." Review of Educational Research 75: 417-453. doi:10.3102/00346543075003417.

Skiba, R. J., L. Poloni-Staudinger, A. B. Simmons, L. R. Renae Feggins-Azziz, and C. G. Chung. 2005. "Unproven Links: Can Poverty Explain Ethnic Disproportionality in Special Education?" The Journal of Special Education 39: 130-144.

Slocumb, P. D. 2001. “Giftedness in Poverty."Gifted Education Communicator 32 (4): 6-11.

Smith, J. R., J. Brooks-Gunn, and P. K. Klebanov. 1997. “Consequences of Growing up Poor for Young Children's Cognitive and Verbal Ability and Early School Achievement." In Consequences of Growing up Poor, edited by G. J., Duncan, and J. Brooks-Gunn, 132-189. New York: Russell Sage. 
Stanford Achievement Test. 2002. Stanford Achievement Test Series. 10th ed. San Antonio, TX: Pearson Assessment.

Taylor, R. 2006. Assessment of Exceptional Students: Educational and Psychological Procedures. Boston, MA: Pearson/Allyn \& Bacon.

Texas Education Agency. 2013. "Texas Performance Reporting System." http://ritter.tea.state.tx.us/ cgi/sas/broker

Trusty, J., S. G. Niles, and J. V. Carney. 2005. "Education-Career Planning and Middle School Counselors.” Professional School Counseling 9: 136-143.

Tyler-Wood, T., and L. Carri. 1993. “Verbal Measures of Cognitive Ability: The Gifted Low SES Student's Albatross." Roeper Review 16: 102-105. doi:10.1080/02783199309553550.

U.S. Bureau of the Census. 2010. “Child Poverty Brief 2009 and 2010: Rates by Race \& Hispanic Origin by State." http://www.census.gov/prod/2011 pubs/acsbr10-05.pdf

U.S. Bureau of the Census. 2012." How the Census Bureau Measures Poverty." https://www.census.gov/ hhes/www/poverty/about/overview/measure.html

Useem, E. L. 1992. "Middle Schools and Math Groups: Parents' Involvement in Children's Placement." Sociology of Education 65: 263-279. doi:10.2307/2112770.

Venn, J. J. 2007. Assessing Students with Special Needs. 4th ed. Upper Saddle River, NJ: Pearson-Merrill/ Prentice Hall.

Vista, A. D., and T. C. Grantham. 2010. "Effects of Parental Education Level on Fluid Intelligence of Philippine Public School Students." Journal of Psychoeducational Assessment 28: 236-248. doi: $10.1177 / 0734282909344416$.

Warne, R. T. 2009. "Comparing Tests Used to Identify Ethnically Diverse Gifted Children: A Critical Response to Lewis, DeCamp-Fritson, Ramage, McFarland, \& Archwamety." Multicultural Education 17 (1): 48-53.

Warne, R. T., B. Anderson, and A. O. Johnson. 2013. “The Impact of Race and Ethnicity on the Identification Process for Giftedness in Utah." Journal for the Education of the Gifted 36 (4): 487-508. doi: $10.1177 / 062353213506065$.

West, J., K. Denton, and E. Germino-Hausken. 2000. America's Kindergartners (NCES 2000-070). Washington, DC: National Center for Education Statistics.

White, K. 1982." The Relation between Socioeconomic Status and Academic Achievement." Psychological Bulletin 91: 461-481. doi:10.1037//0033-2909.91.3.461. 